\title{
Marine Animal-Derived Compounds and Autophagy Modulation in Breast Cancer Cells
}

\author{
Claudio Luparello
}

check for updates

Citation: Luparello, C. Marine Animal-Derived Compounds and Autophagy Modulation in Breast Cancer Cells. Foundations 2021, 1 , 3-20. https://doi.org/10.3390/ foundations 1010002

Academic Editor: Martin Schröder

Received: 2 April 2021

Accepted: 6 May 2021

Published: 17 May 2021

Publisher's Note: MDPI stays neutral with regard to jurisdictional claims in published maps and institutional affiliations.

Copyright: (C) 2021 by the author. Licensee MDPI, Basel, Switzerland This article is an open access article distributed under the terms and conditions of the Creative Commons Attribution (CC BY) license (https:// creativecommons.org/licenses/by/ $4.0 /)$.
Department of Biological, Chemical and Pharmaceutical Sciences and Technologies, University of Palermo, Viale delle Scienze, Edificio 16, 90128 Palermo, Italy; claudio.luparello@unipa.it

\begin{abstract}
It is known that in breast cancer biology, autophagy mainly plays a cytoprotective and antiapoptotic role in vitro, being conceivably responsible for cell resistance to drug exposure and a higher metastatic attitude in vivo. Thus, the development of novel autophagy-targeting agents represents a valuable strategy to improve the efficacy of anticancer interventions. It is widely acknowledged that the enormous biodiversity of marine organisms represents a highly promising reserve for the isolation of bioactive primary and secondary metabolites targeting one or several specific molecular pathways and displaying active pharmacological properties against a variety of diseases. The aim of this review is to pick up selected studies that report the extraction and identification of marine animal-derived extracts or isolated compounds which exert a modulatory effect on the autophagic process in breast cancer cells and list them with respect to the taxonomical hierarchy of the producing species. Where available, the molecular and biochemical aspects associated with the molecules or extracts under discussion will be also summarized.
\end{abstract}

Keywords: marine invertebrates; breast cancer; autophagy; anticancer compounds; apoptosis; cytotoxicity; demosponges; cnidarians; mollusks; echinoderms

\section{A Brief Insight into Autophagy and Breast Cancer Cells}

The term "macroautophagy", hereafter referred as "autophagy", relates to a ubiquitous cellular function that encompasses the engulfing of selected cytoplasmic components by double-membrane structures called autophagosomes, as well as their subsequent delivery to lysosomes and degradation by resident hydrolases. Such a process guarantees the removal and turnover of damaged and aged cytoplasmic organelles or protein aggregates and the recycling of breakdown products for reutilization and energy production, which bring the autophagic flux to completion. Thus, autophagy ensures the maintenance of cellular homeostasis and, upon upregulation, the active response to different cellular stresses such as starvation, cancer, infection, and ischemia [1,2]. The machinery and signalization process of autophagy, which is an evolutionarily conserved, genetically programmed mechanism, is regulated by the expression of more than 30 autophagyrelated genes (ATGs) in concert with other genes with multiple functions, which also include autophagy modulation. ATGs are traditionally classified in functional groups according to whether they operate in the initiation of autophagosome formation, the elongation of phagophores, maturation of autophagosomes, or fusion with late endosomes or lysosomes. Their expression undergoes upstream control by an intricate signalization network which involves AKT/mechanistic targeting of rapamycin (mTOR)-dependent and independent (e.g., mucolipin $\mathrm{Ca}^{++}$channel-mediated) pathways, whose understanding is still incomplete $[3,4]$. Research on autophagy is a field in constant acceleration due to its involvement in the whole aspect of life and medical sciences, and therefore, updated guidelines for standardizing experimentation and monitoring the autophagic process in diverse organisms and conditions are published on a regular basis up to this day [5].

The role played by autophagy in cancer biology is complex since it exhibits a dual nature, being involved both in oncogenesis and in oncosuppression in different conditions, 
which take a variety of cell types, cycle phase distributions, genetic makeups, and also microenvironmental scenarios (e.g., inflammation and hypoxia) into account. Autophagy may help cancer cell survival and tumor promotion by fulfilling the elevated metabolic and energetic demands of actively proliferating and migrating cancer cells, thereby allowing them to overcome oxygen and nutrient deprivation stresses. On the other hand, autophagy may inhibit neoplastic growth, as demonstrated by the correlation between the depletion of key autophagy genes and the increased proliferation of various cancer cytotypes [6].

Concerning breast tumor biology and the autophagic flux, the literature data suggest that in each cancer cell subtype (e.g., luminal, HER2-enriched, and above all, the aggressive triple-negative which exhibits the highest level of basal autophagy), this process mainly plays a cytoprotective and anti-apoptotic role in vitro, being conceivably responsible for cell resistance to drug exposure and a higher metastatic attitude in vivo. It is highly indicative that expression of the LC3B autophagosome marker was found to be higher in node-positive vs. node-negative primary breast tumors and associated with an increased nuclear grade and shortened survival, and that higher expression of the autophagy-promoting factor Beclin-1 in triple-negative breast cancers (TNBCs) was correlated with an increase of lymph node and distant metastases in patients $[7,8]$. On the other hand, a number of autophagy-restraining isolated compounds and secretomes, including the histone deacetylase inhibitors and conditioned media which were examined in [9-12], have been shown to restore the inhibition of survival, the impairment of cell cycle progression, and the induction of cell death programs in breast cancer cell cultures [13-15]. Thus, with the warning to take the specific breast cancer subtype and treatment used into consideration, nevertheless, the cumulative preclinical data obtained prompt the development of novel autophagy-targeting agents as a valuable strategy to improve the efficacy of anticancer interventions.

\section{The Marine Animal Species as a Source of Bioactive Molecules}

The marine environment, which occurs in three-quarters of the globe's surface in seas and oceans, is the largest habitat on earth, featuring an enormous level of biodiversity with many still unknown species, and it is not yet exploited extensively in terms of bioactive natural products. Marine biotechnology and pharmacology represent key ever-evolving issues based on the utilization of marine natural resources [16,17]. In fact, animal adaptation processes for the different and sometimes hostile aquatic environments have led to the promotion and accumulation of a remarkable genetic and biochemical variability, with the consequence that the compounds produced often display prominent differences with respect to those from terrestrial species. Within this context, for example, biotic factors such as the need for interindividual signalization and defense against predators, infective agents, and UV radiations prompted sessile species to develop complex strategies via chemical communication through very disparate metabolites, which is known to encompass different taxonomic lineages and even kingdoms. The study of these unique marine species-derived metabolites, whose peculiar chemical scaffolds can also be utilized for the design of analogs with increased bioavailability and efficacy and less toxicity, offering great potential for the development of new classes of molecules aimed at various applications, encompassing health management, biomaterial engineering, and environmental remediation [18,19].

Thus, to cite just a few examples, anticancer compounds have been found among the primary and secondary metabolites of starfishes and Mediterranean ascidians [20,21], and extracts or isolated molecules obtained from marine invertebrates have been proven to exert a modulatory effect on collective cell migration, a process at the basis of different biological events such as neoplastic cell metastasization and wound repair [22]. Chemicals with histone deacetylase inhibitory properties, whose wide range of potential biomedical applications is generally acknowledged, have also been extracted and identified in preparations from marine invertebrates [23]. The contribution of marine vertebrates to the food, biomedical, and pharmaceutical sectors has been mainly provided by fish oils, containing long-chain $\omega-3$ polyunsaturated fatty acids, vitamin E, essential aminoacids, and bioactive 
peptides exerting antioxidant, anti-allergic, and angiotensin-I-converting enzyme (ACE) inhibitory effects. On the other hand, the processing of by-products of fish, shrimps, crabs, and squids have also been proven to be abundant sources of chitin, lipids, and proteins, granting a number of beneficial properties such as being antimicrobial, anticancer, and anticoagulant, among others [24,25].

It is well-known that invertebrates are endowed with a remarkable ability to regenerate tissue and organs, and that the efficiency of this process is guaranteed by an appropriate regulation of autophagy. In addition, autophagy is a survival mechanism allowing aquatic organisms to withstand different stress conditions, such as hyperthermia and exposure to toxic compounds [26,27]. By considering the things mentioned, the aim of this review is to pick up selected studies that report the extraction and identification of marine animalderived mixed fractions or isolated compounds which exert a modulatory effect on the autophagic process in breast cancer cells and list them with respect to the taxonomical hierarchy of the producing species. Where available, the molecular and biochemical aspects associated with the molecules or extracts under discussion will be also summarized.

\section{Autophagy Modulators from Porifera}

Most of the information available in the literature on compounds targeting autophagy in breast tumor cells come from studies performed on demosponges ("siliceous sponges"). These species belong to the phylum Porifera, the oldest metazoan group on Earth, to which sessile organisms belong, displaying a simple structure and being endowed with specialized cells that are not organized into tissues and organs. The cells lining the internal system of canals and chambers ("choanocytes") ensure filtering activity, whereas the rest of the body is filled with a collagenous matrix ("mesohyl") harboring cells, sponging fibers, and skeletal spicules and covered by a skin made of T-shaped or flat pinacocytes [28]. The data on the autophagy modulators obtained from these organisms will be presented and discussed in chronological order.

The genus Haliclona (Grant, 1841; Demospongiae, Haplosclerida: Chalinidae) includes demosponges widely distributed around the world and, in particular, populating the North Sea, the western Mediterranean Sea and the Atlantic Ocean. They show a relatively smooth surface with several pores and can be found as encrusting species growing over coral rubbles [29]. In 2013, Yamazaki et al. [30] reported the cytotoxic activity of the pentacyclic alkaloid papuamine $(1 S, 2 E, 4 E, 6 S, 7 R, 12 S, 14 R, 20 R, 22 S, 27 R)-15,19$ diazapentacyclo[18.7.0.0 $\left.0^{6,14} \cdot 0^{7,12} \cdot 0^{22,27}\right]$ heptacosa-2,4-diene, Figure 1), the major constituent of these sponges, in MCF-7 breast cancer cells.

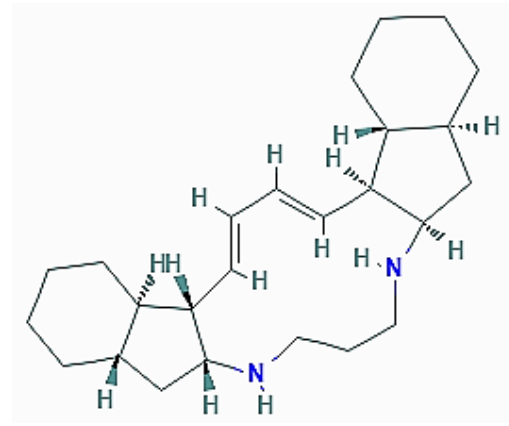

Figure 1. 2D structure of papuamine. (https://pubchem.ncbi.nlm.nih.gov/compound/Papuamine, accessed on 26 March 2021).

A more detailed molecular examination of the effect exerted on MCF-7 cells by the alkaloid at concentrations at or greater than $5 \mu \mathrm{M}$ demonstrated the expression of LC3, a central component of the autophagy process, as revealed by confocal microscopic observations of the time-dependent increase of LC3-associated fluorescence intensity from $4 \mathrm{~h}$ of exposure onward. In addition, the accumulation of the lipidated LC3-II form, a standard marker for autophagosomes [5], from early stages of cell incubation with papuamine was observed 
through Western blot experiments by Kanno et al. [31]. According to their hypothesis, which was also advanced in the light of the collateral assays performed, papuamine could target mitochondria, inducing their dysfunction and membrane depolarization and leading to their sequestration into autophagosomes ("mitophagy") [32]. Then, the subsequent JNK activation and release of cytochrome $C$ would conceivably trigger the decrease of cell survival and the promotion of apoptotic cell death. Interestingly, papuamine was shown to exhibit synergy when coadministered with doxorubicin to MCF-7 cells, probably on the basis of a shared activation of JNK phosphorylation [33], thus suggesting the introduction of the alkaloid in a combined chemotherapy regime for the treatment of breast cancer. The anticancer effect of papuamine on non-small cell lung cancer cells was also reported [34].

Haliclona caerulea (Hechtel, 1965; Demospongiae, Haplosclerida: Chalinidae) is a blue sponge populating the shallow waters, dredged channels, and artificial lagoons of the Pacific and Western Central Atlantic oceans. It is characterized by a skin studded with thick-walled, volcano-shaped oscula protruding from its smooth surface (Figure 2) [35].

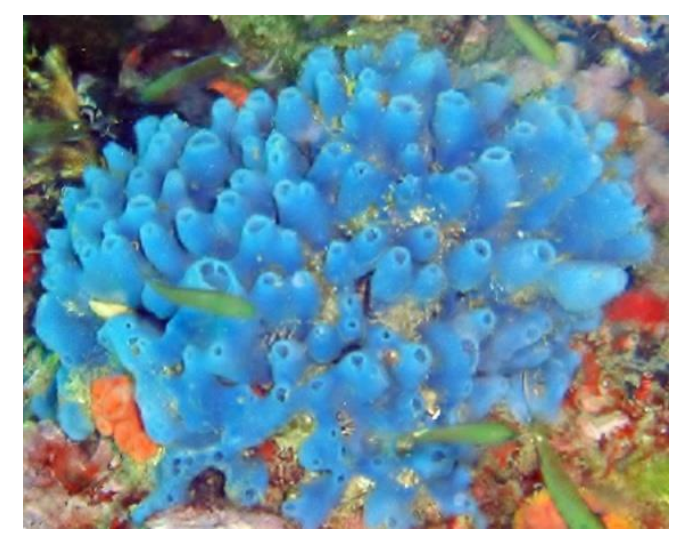

Figure 2. A specimen of H. caerulea demosponge. Author: Chaloklum Diving (CC BY 3.0); http: / / eol.org/data_objects/31317401 (accessed on 26 March 2021).

From this sponge, Carneiro et al. [36] isolated halilectin-3, an N-acetyl group-binding heterotrimeric lectin classified as a pigment protein since it interacts with the hydrophobic blue chromophore-597. Subsequently, when Nascimento-Neto et al. [37] examined the effect of the molecule on MCF-7 breast cancer cells, they found that cell adhesion was impaired, and cell cycle arrest at the $G_{1}$ phase, apoptosis, and autophagy were induced. In particular, the latter represented the earliest effect of halilectin-3 treatment, which was proven to upregulate MAP1LC3B gene expression and accumulate LC3-II vs. unlipidated LC3-I molecules already at $6 \mathrm{~h}$ from administration. Conceivably, autophagy was triggered by lectin-induced downregulation of BCL2 and upregulation of TP53 genes, the latter also likely being responsible for cell cycle impairment. On the other hand, although the exact mechanism of apoptosis promotion was not clarified, in light of the increased expression of both caspase- 8 and -9 observed, it was speculated that the impaired adhesion-dependent anoikis and some signalization by potential lectin binding to the surface receptors might induce both the intrinsic and extrinsic apoptosis pathway.

Cliona celata (Grant, 1826; Demospongiae, Clionaida: Clionaidae) is a cosmopolitan organism showing a body composed of a large network of inhalant sieve-like openings (Figure 3). It is a perforating sponge which creates holes in limestones or other calcareous surfaces, such as oysters' shells, which they live on. 


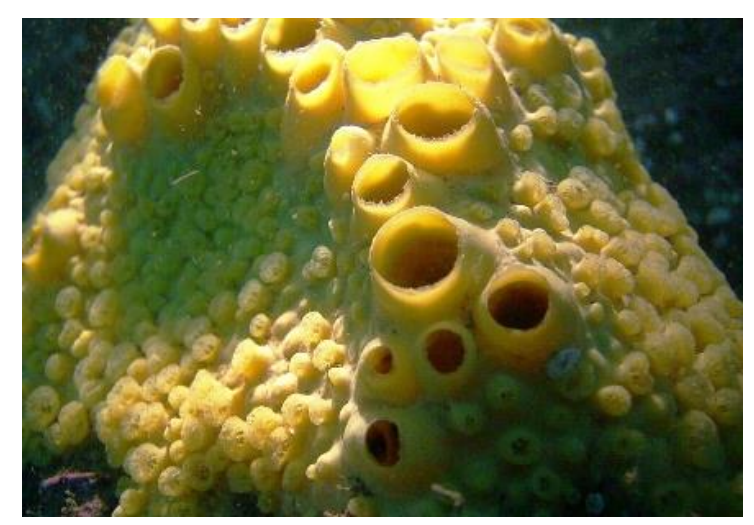

Figure 3. A specimen of C. celata demosponge (licensed under the Creative Commons AttributionShareAlike 4.0 International License) [38].

From methanolic extracts of this organism, Keyzers et al. [39] isolated four aminosteroids (clionamine A-D), which appeared to be able to induce autophagosome formation in MCF-7 breast cancer cells, as revealed by the accumulation of cytoplasmic green fluorescent protein (GFP)-LC3 puncta, that being clionamine A $((1 R, 2 S, 4 S, 7 S, 8 R, 9 S, 12 S, 13 S, 16 S)-16$ amino-7-[(E)-3,4-dimethylpent-1-enyl]-7-hydroxy-9,13-dimethyl-5-oxapentacycloicosan-6one; Figure 4A), the most powerful autophagy stimulator. Subsequently, total synthesis of one of the aminosteroids (clionamine B) $((1 R, 2 S, 4 S, 7 S, 8 R, 9 S, 12 S, 13 S, 16 S, 18 S)-16$-amino-7hydroxy-9,13-dimethyl-7-(4-methylpentyl)-5-oxapentacyclo[10.8.0.0 $\left.0^{2,9} \cdot 0^{4,8} \cdot 0^{13,18}\right]$ icosan-6one; Figure 4B) was obtained for the first time, starting from the plant sapogenin tigogenin, and the synthetic compound was proven to strongly promote autophagy in MCF-7 cells with a potency similar to that of clionamine A [40].

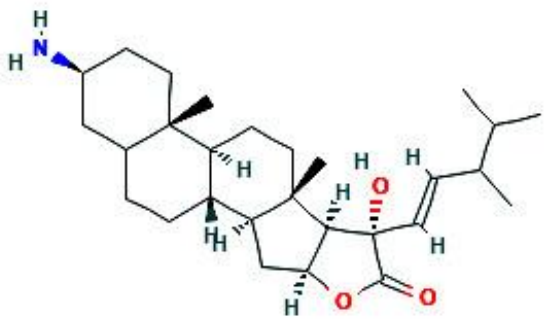

A

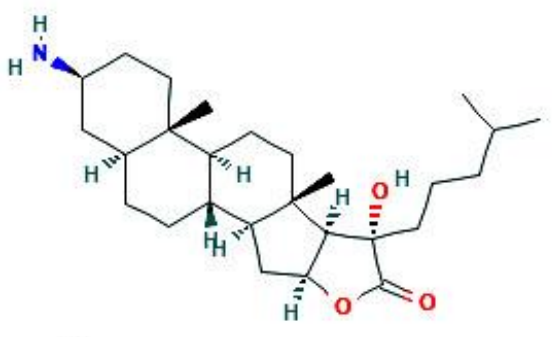

B

Figure 4. 2D structures of (A) clionamine A (https:/ / pubchem.ncbi.nlm.nih.gov/compound/Cliona mine-A\#section=Structures, accessed on 26 March 2021) and (B) clionamine B (https: / / pubchem.nc bi.nlm.nih.gov / compound/Clionamine-B\#section=2D-Structure, accessed on 26 March 2021).

The sponges of the genus Psammaphysilla, and currently Pseudoceratina (Carter, 1885; Demospongiae, Verongiida: Pseudoceratinidae), are distributed across the Red Sea and the Indo-Pacific ocean and display a smooth, conulose, or tuberculate surface and a hard body with a dense collagenous matrix containing sparse skeletal fibers (Figure 5) [41]. 


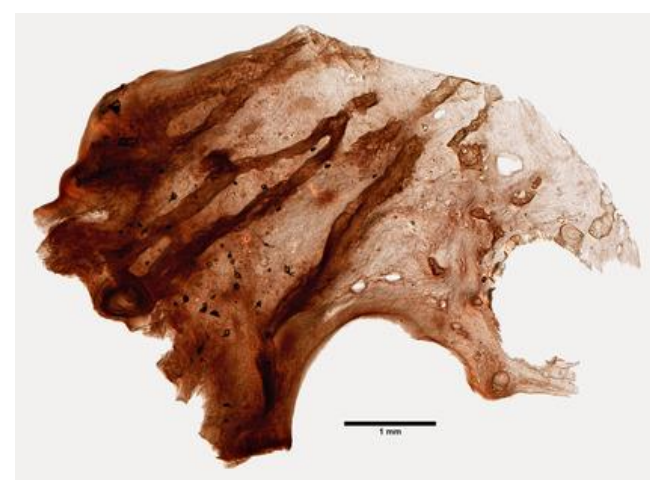

Figure 5. A specimen of the Psammaphysilla kelleri demosponge (YPM 086046), courtesy of the Yale Peabody Museum of Natural History. Photo by D. Drew, 2017 (http:/ / peabody.yale.edu, accessed on 26 March 2021).

Psammaplin A ((2E)-3-(3-bromo-4-hydroxyphenyl)-N-[2-[2-[[(2E)-3-(3-bromo-4hydroxyphenyl)-2-hydroxyiminopropanoyl]amino]ethyldisulfanyl]ethyl]-2-hydroxyiminopropanamide; Figure 6), the first one of the phenolic compounds isolated from these Porifera sponges, is a brominated, tyrosine-derived disulfide dimer initially described as an antimicrobial and antifungal compound and subsequently proven to act as an enzymatic inhibitor against topoisomerase, farnesyl protein transferase, chitinase, histone deacetylases, and DNA methyltransferases, thereby also demonstrating anticancer activity [23,42-45].

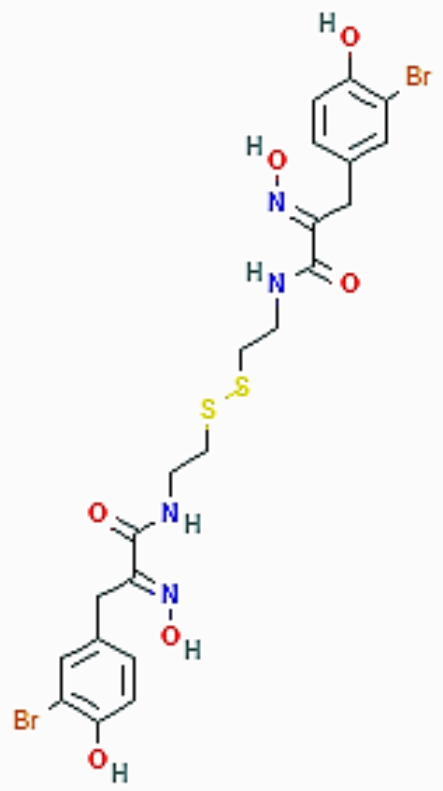

Figure 6. 2D structure of psammaplin A (https:/ / pubchem.ncbi.nlm.nih.gov/compound/Psamma plin-A\#section=2D-Structure, accessed on 26 March 2021).

In 2015, Kim et al. [46] investigated the antitumor effect of psammaplin A as an inhibitor of sirtuin-1 (SIRT1) histone deacetylase on doxorubicin-resistant MCF-7/adr human breast cancer cells, which are strongly susceptible to the cytotoxic effect of the marine compound. Among the data collected, psammaplin inhibition of SIRT1 was proven to promote autophagy, as revealed by the increased intracellular formation of acidic vacuolar organelles and the increased expression level of LC3, ATG-3, -5, -7, and -12, as well as beclin-1, the latter being a core component of the class III phosphatidylinositol-3 kinase (PI3K) complex required for autophagosome formation [47]. As a further confirmation of psammaplin A-promoted autophagic flux, cell exposure to the compound also induced the downregulation of the p62/SQSTM1 protein, an event linked to autophagosome degrada- 
tion [5]. Both knockdown and transfection experiments demonstrated that induction of autophagy was dependent upon the SIRT1 inhibition pathway. Of note, SIRT1 inhibition determined the nuclear accumulation of acetylated p53 and the upregulation of its target genes $D R A M$, code for the damage-regulated autophagy modulator involved in autophagy initiation events [48], and CDKN1A, code for p21/WAF1, whose role played in the onset of autophagy is acknowledged [49]. The anti-breast cancer effect of psammaplin A was also demonstrated in a xenograft model, indicating that the compound has a potential therapeutic role for clinical use.

Xestospongia exigua (Kirkpatrick, 1900; Demospongiae, Haplosclerida, Petrosiidae) populates the shallow lagoons and the fringing reefs of the Indo-Pacific area and displays a spreading, irregular surface endowed with branches, fingers, blades, and scattered oscula (Figure 7) [50].

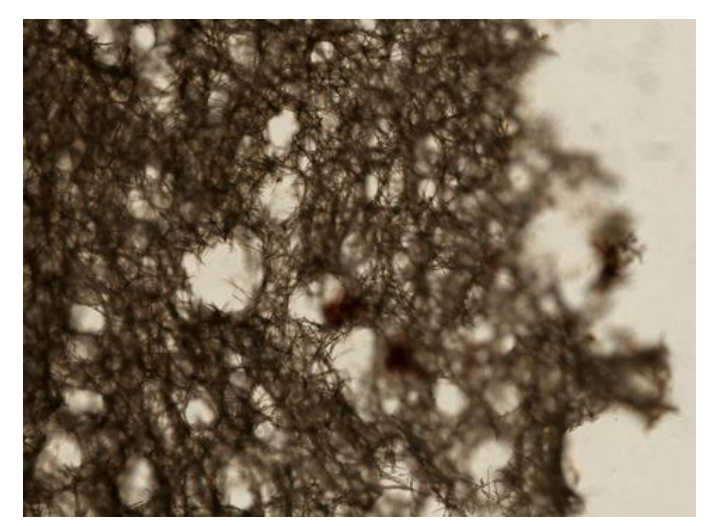

Figure 7. A specimen of the X. exigua demosponge (YPM 086991), courtesy of the Yale Peabody Museum of Natural History. Photo by D. Drew, 2018 (http:/ / peabody.yale.edu, accessed on 26 March 2021).

This organism proved to be a good source of araguspongine/xestospongine alkaloids, dimeric 2,9- disubstituted 1-oxaquinolizidines that have been shown to possess a variety of pharmacological activities [51,52]. In 2015, Akl et al. [53] reported that araguspongine C $\left((1 R, 8 R, 10 S, 15 R, 22 R, 29 S)-9,30\right.$-dioxa-11,25-diazapentacyclo[20.6.2.2 $2^{8,11} \cdot 0^{10,15} \cdot 0^{25,29}$ ]dotriacontane-1,15-diol; Figure 8) exerted an antiproliferative effect on a panel of breast cancer cell lines in culture. More detailed analyses aimed at identifying the cause of the accumulation of vacuoles in BT-474 breast tumor cells revealed the dose-dependent ability of araguspongine $\mathrm{C}$ to stimulate autophagy, as revealed by the increase in the accumulation of fluorescent autophagosomes and the upregulation of the total protein levels of LC3, Beclin-1, and ATG-5, -7, and -16L1. Molecular studies on the putative mechanism of the araguspongine $\mathrm{C}$ promotion of autophagy demonstrated that the compound directly inhibited the expression and activation of c-Met and HER2 tyrosine kinase receptors which, in turn, suppressed the downstream signalization by the PI3K/Akt/mTOR pathway. Concurrently, araguspongine $\mathrm{C}$ determined the downregulation of the IP3 receptor by breast cancer cells. Taken together, these effects of the exposure of araguspongine $C$ were conceivably responsible for the activation of autophagy and subsequent inhibition of BT- 474 cell growth and proliferation. Interestingly, araguspongine $C$ recently showed promising results in primary and secondary angiogenesis screening modules, thereby also representing a future anti-angiogenic drug candidate [54]. 


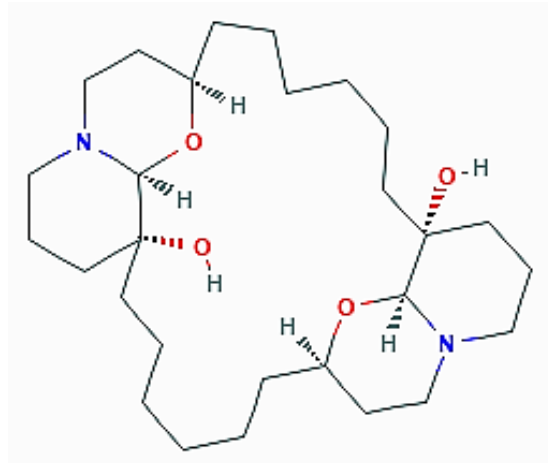

Figure 8. 2D structure of araguspongine C (https:/ / pubchem.ncbi.nlm.nih.gov/compound/Aragus pongine-C\#section=Structures, accessed on 26 March 2021).

Fascaplysinopsis (Demospongiae, Dictyoceratida: Thorectidae) is a rare monotypic genus as it contains only one species, F. reticulata (Hentschel, 1912; Figure 9), a hermaphroditic demosponge distributed in the Western Central Pacific area and endowed with a membranous and opaque variform surface with large conules and ridges [55].

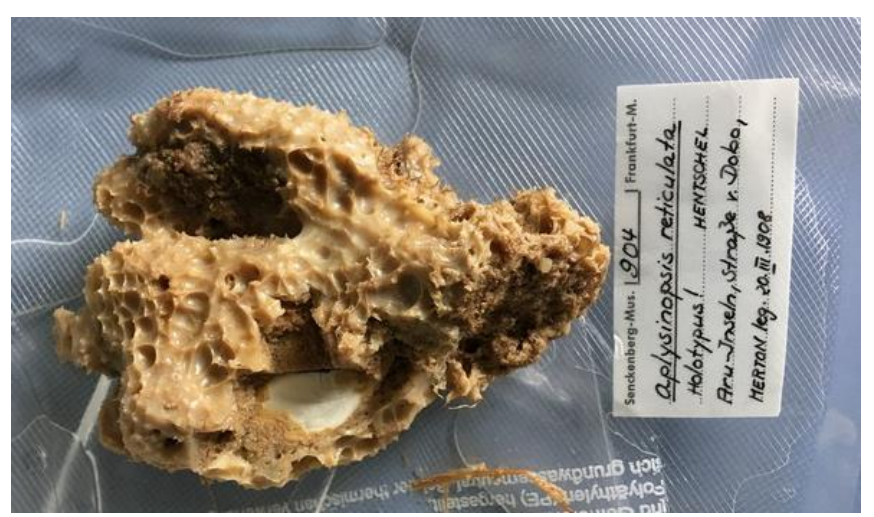

Figure 9. A specimen of the F. reticulata demosponge. Author: Hooper, John (http:/ /www.marine species.org / aphia.php? $\mathrm{p}=$ image\&tid=165315\&pic=142739, accessed on 26 March 2021). Licensed under the Creative Commons Attribution-Noncommercial-Share Alike 4.0 License.

Extracts of this sponge are rich in the indole alkaloid fascaplysin (3-aza-13-azoniapentacyclo[11.7.0.0.1 $\left.0^{2,10} \cdot 0^{4,9} \cdot 0^{14,19}\right]$ icosa-1(13),2(10),4,6,8,11,14,16,18-nonaen-20-one; Figure 10) and related compounds endowed with selective cyclin-dependent kinase 4 inhibitory and DNA intercalation properties [56], which are the basis of the anti-angiogenic and anticancer properties of both the parental molecule and its derivatives [57-59]. In 2017, Sharma et al. [60] studied the molecular mechanism of the anti-breast tumor effect exerted by the analog 4-chloro fascaplysin on MDA-MB231 cells and, besides other results indicating the onset of mitochondrial dysfunction and apoptosis, found that the alkaloid determined the increase in the number of fluorescent acidic vacuolar organelles and the upregulation of LC3-II, as revealed by immunoblotting. Their cumulative data depicted the 4-chloro fascaplysin-triggered growth inhibition of MDA-MB231 cells as being a result of the simultaneous induction of autophagy and apoptosis, the latter stimulated by the loss of mitochondrial transmembrane potential. Both events converged in the activation of caspase-3, and in this case, the Akt/mTOR pathway was also severely abrogated, which contributed to autophagy promotion. Interestingly, the in vitro data were corroborated by in vivo evidence of solid tumor growth inhibition in murine models, thereby representing a preclinical rationale for the development of anti-tumoral therapeutic agents, also in the light of the very good ADMET profile shown by 4-chloro fascaplysin. 


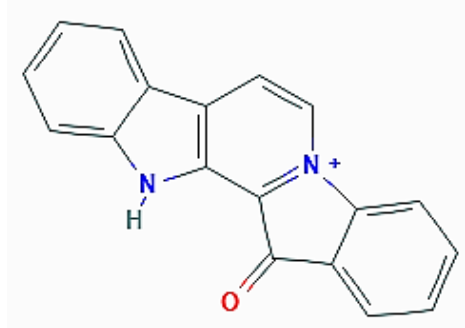

Figure 10. 2D structure of fascaplysin (https:/ / pubchem.ncbi.nlm.nih.gov/compound/Fascaplysin\# section=2D-Structure, accessed on 26 March 2021).

The species of the genus Aaptos (Gray, 1867; Demospongiae, Suberitida: Suberitidae) are tropical and subtropical organisms mainly distributed in the Western Central Atlantic and Mediterranean areas. They show a spherical or lobate shape and a characteristic radial skeleton that contains "strongyloxeas", rhabds which are rounded at one end and pointed at the other (Figure 11).

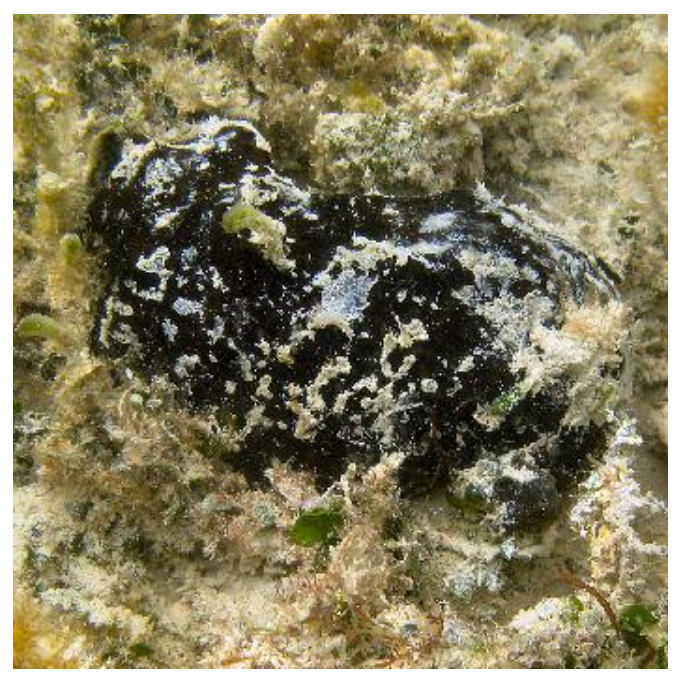

Figure 11. A specimen of the Aaptos pernucleata demosponge. Photographer: C. G. Messing, Diaz, M.C., Kohler, K.E., Reed, J.K., Ruetzler, K., Van Soest, R.W.M., Wulff, J, and Zea, S. 2010. South Florida. Publisher: Freeman, Chris (http:/ / porifera.myspecies.info/taxonomy/term/22534, accessed on 26 March 2021 (CC BY-NC 3.0)).

Bioactivity-guided fractionation of the methanolic extracts obtained from these organisms resulted in the isolation of aaptamine alkaloids, among which isoaaptamine (11-methoxy-2methyl-2,6-diazatricyclo[7.3.1. $\left.0^{5,13}\right]$ trideca-1(13),3,5,7,9,11-hexaen-12-ol; Figure 12) was the most prominent in the active fraction and showed the most potent cytotoxic activity on T47-D breast cancer cells, as revealed by a short-term MTT assay and long-term colony formation assay. The anti-proliferative activity of the alkaloid on different tumor cell lines, including MDA-MB 231, had already been reported by Dyshlovoy et al. [61]. Further and more detailed studies on the T47-D cell model delineated that the inhibitory effect of isoaaptamine was based upon the induction of both apoptosis and autophagy, the latter revealed by the dose- and time-dependent increase of acridine orange-positive vacuoles, upregulation of LC3-II and p62/SQSTM1, and downregulation of mTOR. In addition, a significant increase in the generation of reactive oxygen species (ROS), as well as the disruption of the mitochondrial transmembrane potential, was also demonstrated. Thus, the cumulative data allowed for the conclusion that isoaaptamine-promoted T-47D cell apoptosis and autophagy was accomplished via cellular Nrf1/Keap1 antioxidant depletion and p62-regulated ROS accumulation [62]. 
<smiles>COc1cc2ccnc3c2c(c1O)N(C)C=C3</smiles>

Figure 12. 2D structure of isoaaptamine (https:/ / pubchem.ncbi.nlm.nih.gov/compound/Isoaapta mine\#section=2D-Structure, accessed on 26 March 2021).

\section{Autophagy Modulators from Cnidaria}

Cnidaria, also called coelenterates, are animals that share the radial symmetry of the body, the lack of cephalization, and the organization of cells in tissues, although they lack organs. In particular, cnidarians possess two cell layers, the ectoderm and the endoderm, separated by the mesoglea, an elastic jelly-like substance in which a network of supporting fibers is present. Members of the group, the polyps, secrete external skeletons made of chitin or calcium carbonate, whereas the alcyoniarians are endowed with an internal skeleton. Only one member of this phylum has been reported to produce compounds able to modulate autophagy in breast tumor cells.

Klyxum flaccidum, originally named Alcyonium flaccidum (Tixier-Durivault, 1966; Anthozoa, Alcyonacea: Alcyoniidae), a coral populating the Western Central Pacific area and the coasts of Madagascar, forms lobate and quite small colonies. The non-retractile polyps are clustered on the lobes, and the sclerite-containing mesoglea (the "coenenchyme") form cone-shaped prominences (Figure 13) [63]. In 2018, Weng et al. [64] submitted a small library of purified marine natural molecules to a screening aimed at identifying potential activators of peroxisome proliferator-activated receptor $\gamma(\operatorname{PPAR} \gamma)$, a therapeutic target for anticancer therapy [65] in MCF-7 breast tumor cells, and identified the sterol 33,11-dihydroxy-9,11-secogorgost-5-en-9-one obtained from K. flaccidum [66] as a receptor activator through a luciferase reporter assay. The sterol was proven to exert a cytotoxic effect on the neoplastic cells via the induction of caspase 3-dependent apoptosis and autophagy. In particular, it determined the ROS-mediated DNA damage and the decrease of cyclin D1, cyclin-dependent kinase 6, Bcl-2, phospho-ERK, and phospho-p38, which are responsible for the impairment of cell cycle progression and onset of apoptosis.

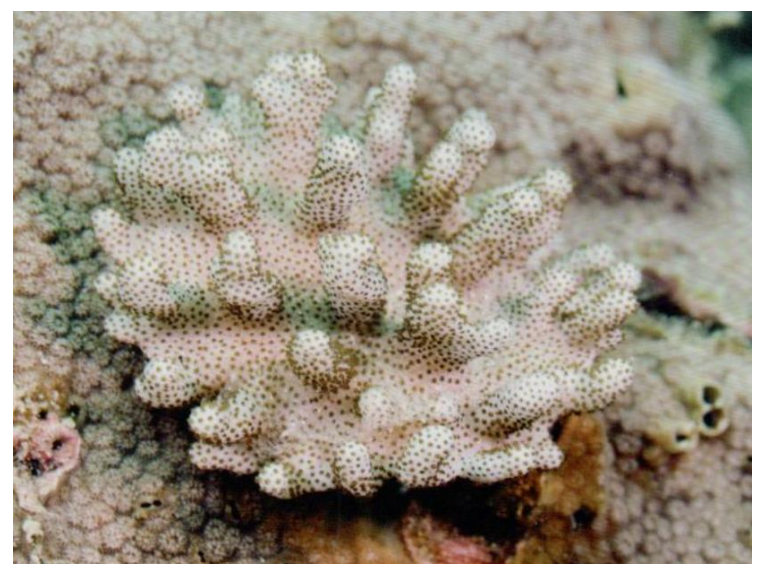

Figure 13. A specimen of K. flaccidum coral, taken from the Dongsha Bafang Coral Ecological Illustrated Book, 2017. Authors: Dai Changfeng and Qin Qixiang. Marine National Park Management Office (CC BY-NC). 
The promotion of autophagy was revealed by the dose-dependent accumulation of acidic vesicular organelles in the cytoplasm and the upregulation of LC3-II and p62, the latter also being confirmed in sterol-treated MDA-MB231 tumor cells. The cumulative data obtained suggested the translational potential of the compound in breast cancer therapy.

\section{Autophagy Modulators from Mollusca}

Mollusca are the largest marine phylum and are characterized by a bilateral simmetry, the absence of segmentation, and the appearance of organs, such as the characteristic "radula" used for feeding, and a nervous system. Their dorsal body wall ("mantle") covers the visceral mass and, in many species, is responsible for the formation of a shell made of calcium carbonate and conchiolin. In addition, in the case of this phylum, only one member has been reported to produce compounds able to modulate autophagy in breast tumor cells.

Crassostrea virginica (Gmelin, 1791; Bivalvia, Ostreida: Ostreidae; Figure 14), known as the eastern oyster, is a bivalve mollusk endowed with a calcite shell that can be found naturally in a great diversity of habitats along the coasts of the western Atlantic Ocean from Canada to Argentina. It is known that oysters are rich sources of the sphingolipid ceramide $N$-methylaminoethylphosphonate (CMAEPn; Figure 15), which is concentrated in their adductor, mantle, gills, and viscera $[67,68]$. On the other hand, ceramide and other sphingolipid mediators are involved in the mechanism of signalization that regulates cancer progression, and ceramide has been proven to play a key role in cancer chemotherapy metabolism and efficacy, thus emerging as a potential strategy for restraining carcinogenesis [69]. Chintalapati et al. [70] studied the biological bases of the cell death effect exerted by CMAEPn isolated from C. virginica on hormone-dependent MCF-7 and independent MDA-MB435 breast cancer cells.

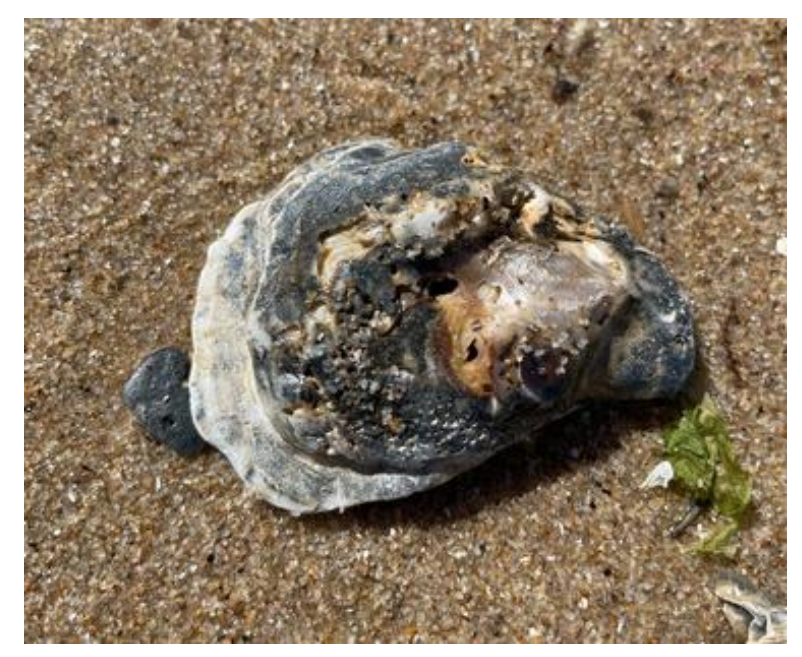

Figure 14. A specimen of the C. virginica oyster. (C) johnbotany (https:/ / www.inaturalist.org/photos /117869887, accessed on 26 March 2021 (CC BY-NC)). 


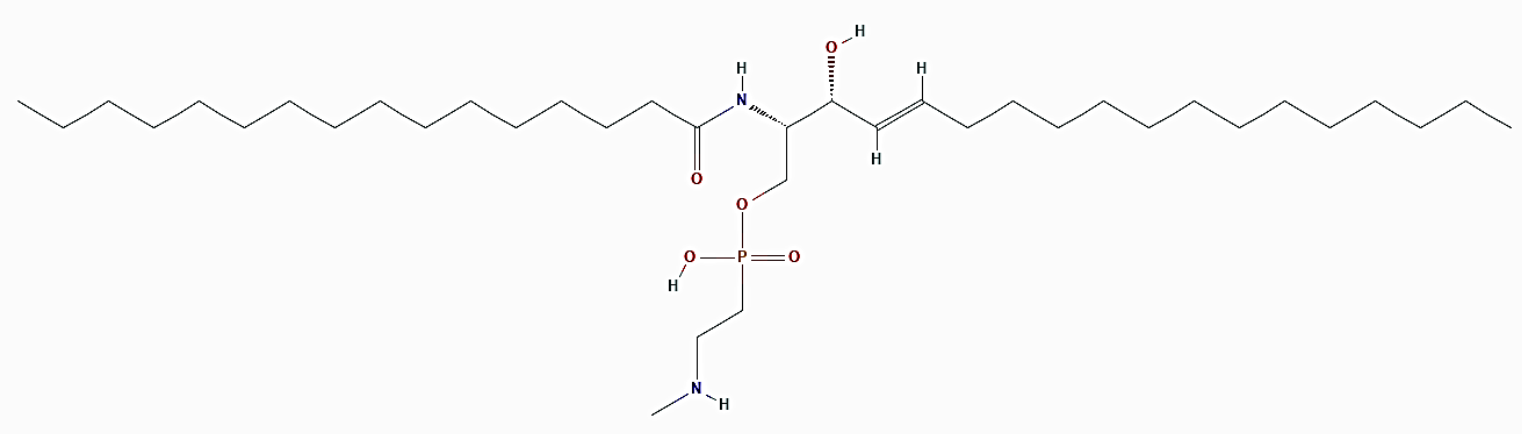

Figure 15. 2D structure of ceramide $N$-methylaminoethylphosphonate (https:/ / pubchem.ncbi.nlm.nih.gov/compound/64 44126, accessed on 26 March 2021).

Their results demonstrated that oyster ceramide down-regulated VEGF, EGF, and PI3K, which control some of the main signalization pathways associated with breast tumor progression, and inhibited the phosphorylation and degradation of Ikb, which blocks $\mathrm{Nf \kappa B}$ nuclear translocation by masking its nuclear localization sequence [71]. In line with the published data [72-74], these molecular events appeared to stimulate autophagy in exposed cells, as revealed by the accumulation of fluorescent autophagosomes and the increase of the beclin-1 protein level. It is noteworthy that CMAEPn was also able to inhibit angiogenesis in vitro and in vivo, thereby resulting in it being a promising tool relevant to counteracting breast tumorigenesis.

\section{Autophagy Modulators from Echinodermata}

Echinodermata are invertebrates characterized by the presence of a hard, spiny covering or skin, a mesodermal skeleton endowed with calcareous plates or ossicle, and, apart from a few exceptions, a pentaradial symmetry. This phylum represents the second-largest grouping of deuterostomes after the chordate, in light of the roughly 7000 extant species contained. Two species of echinoderms have been reported to produce compounds able to modulate autophagy in breast tumor cells.

Arbacia lixula (Linnaeus, 1758; Echinoidea, Diadematoida: Arbaciidae, Figure 16) is a medium-sized deep black sea urchin populating the shallow waters of the Mediterranean area and the coasts of the Azores, Madeira, and Canary Islands.

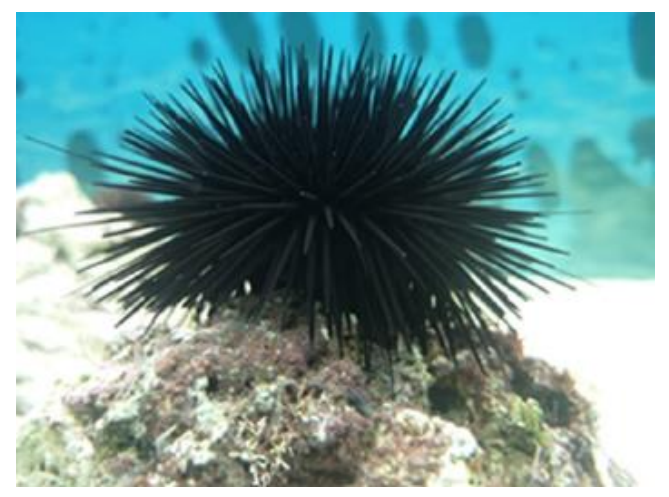

Figure 16. A specimen of the A. lixula sea urchin. Taken from [75].

Holothuria tubulosa (Gmelin, 1788; Holothuroidea, Aspidochirotida: Holothuridae, Figure 17) is a roughly cylindrical brownish sea cucumber abundant in the sandy or rocky substrates of the eastern Atlantic Ocean and Mediterranean Sea. This benthic echinoderm, which displays a tough tegument covered with many dark-colored papillae, represents an excellent animal system for the study of the morphometric and humoral responses during tissue repair [76,77]. 
Both organisms have been widely used as models to examine the effects of anthropogenic chemical and noise pollution [78-80].

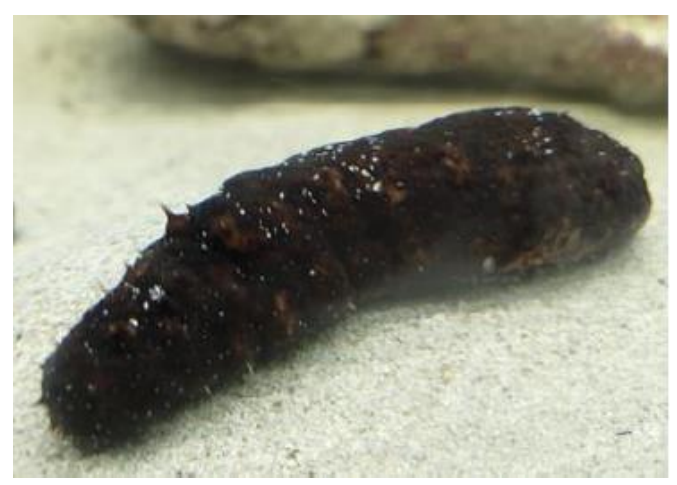

Figure 17. A specimen of the H. tubulosa sea cucumber. Taken from [81].

On the basis of the acknowledged diverse biological and pharmacological properties shown by the compounds and extracts from sea urchins and holothurians [82-85], in search of novel potential anti-breast cancer preparations, crude and $<10 \mathrm{kDa}$-filtered fractions of cell-free aqueous extracts of the coelomic fluids from A. lixula and H. tubulosa were administered to MDA-MB231 TNBC cells, and the biological aspects of the observed cytotoxic effects were investigated [75,81].

Concerning A. lixula's preparations, the sole filtered extract was proven to promote autophagic cell activity, as revealed by the accumulation of acidic vesicular organelles and the increase of the beclin-1, LC3-II, and total LC3 protein levels. Of note, autophagy upregulation occurred in parallel with ROS overproduction and the blocking of the cell cycle at the S-phase with no evidence of dissipation of the mitochondrial transmembrane potential and the onset of apoptosis. The obtained results allowed for the speculation that (1) the increase of the endogenous ROS levels could be a consequence of cellular metabolic stress and impairment of the antioxidant system in the absence of mitochondrial potential dysfunction; (2) autophagy upregulation could be a result of intracellular signalization switched on by ROS, acting as redox signaling molecules; and (3) autophagy might be responsible for the blocking of the cell cycle at the S-phase, analogous with the data produced in [86]. As an alternative, the upregulation of the autophagic activity was interpreted as a cell repair mechanism aimed at counteracting ROS-induced necrotic death but ineffective at ensuring cell survival.

Concerning H. tubulosa's extracts, by evaluating the same endpoints as for A. lixula's preparations, both the crude and filtered samples were proven to promote autophagy, although the latter ones appeared more powerful in inducing an early stimulation at $24 \mathrm{~h}$ from exposure. At this time point, autophagy upregulation appeared to parallel mitochondrial transmembrane potential dissipation, whereas ROS overproduction was undetectable and remained unchanged thereafter. Such evidence suggested that the autophagic program activated by the extracts was of the "mitophagic" type given the absence of apoptotic death, likely due to the elimination of damaged mitochondria that reduced the intracytoplasmic release of cytochrome $C$, a known inductor of intrinsic apoptosis [87]. On the other hand, the autophagic clearance of the damaged mitochondria might be responsible for the inability to detect increased ROS accumulation [88].

The above-discussed results represent a good starting point for the identification of the water-soluble bioactive component(s) present in the extracts, with the aim to develop novel prevention or treatment agents efficacious against highly metastatic breast carcinomas.

\section{Conclusions}

In 2020, the World Health Organization reported the occurrence of 2.3 million women diagnosed with breast tumors and 685,000 deaths globally, thereby confirming that this 
neoplastic histotype has surpassed lung cancer as the most commonly diagnosed one and represents the world's most prevalent neoplasia $[89,90]$. Since the currently available treatments are not fully working with most breast cancer patients, the procurement of alternative prevention or therapeutic agents appears to be imperative, including nanomaterials $[91,92]$ to improve both medication and the quality of life of patients.

It is widely acknowledged that the enormous biodiversity of marine organisms represents a highly promising reserve for the isolation of bioactive primary and secondary metabolites targeting one or several specific molecular pathways and displaying active pharmacological properties against a variety of diseases. Among the anticancer compounds searched in extracts from marine organisms, in this review, a focus was put on modulators that control and modify autophagy in breast cancer cells. Table 1 summarizes, in a synoptic way, the invertebrate species of origin, the substances, and the autophagy modulatory effects discussed in the text. Attention on the autophagic process has increased over time due to its critical role in dictating life or death cellular decisions, leading to a wide range of biomedical applications (e.g., [93,94]). In addition, the role of marine natural products in the induction and inhibition of autophagy and its outcome in tumorigenesis have been widely acknowledged [95]. Marine invertebrates have contributed to this field, with a number of compounds displaying autophagy-regulating properties toward breast tumor cell models, and demosponges have been the most investigated ones to date. Nevertheless, despite the extent of the marine environment's biomedical chest, current research on this topic is quite limited, and further study efforts are needed to expand the list of tested bioactives discovered across the different taxonomic groups, as well as in vivo work and human trials to ensure the effective chemotherapeutic efficacy of marine compounds as treatment options for breast cancer.

Table 1. Autophagy-modulating substances from marine species.

\begin{tabular}{|c|c|c|}
\hline Organism of Origin & Substance & Autophagy-Related Effects \\
\hline Haliclona genus (Porifera) & Papuamine & $\begin{array}{l}\text { Accumulation of total LC3 and LC3-II; } \\
\text { possible mitophagy }\end{array}$ \\
\hline H. caerulea (Porifera) & Halilectin-3 & $\begin{array}{l}\text { Upregulation of MAP1LC3B gene } \\
\text { expression; accumulation of LC3-II }\end{array}$ \\
\hline C. celata (Porifera) & Clionamine A-D & $\begin{array}{l}\text { increase of cytoplasmic green } \\
\text { fluorescent protein (GFP)-LC3 puncta }\end{array}$ \\
\hline $\begin{array}{l}\text { Psammaphysilla genus } \\
\text { (Porifera) }\end{array}$ & Psammaplin A & $\begin{array}{c}\text { Increase of acidic vacuolar organelles; upregulation of } \\
\text { LC3, ATG-3, -5, -7, -12, and beclin-1; downregulation } \\
\text { of p62/SQSTM1 protein }\end{array}$ \\
\hline X. esigua (Porifera) & Araguspongine $\mathrm{C}$ & $\begin{array}{l}\text { Increase of fluorescent autophagosomes; upregulation } \\
\text { of total LC3, Beclin-1, ATG-5, -7, and -16L1 }\end{array}$ \\
\hline F. reticulata (Porifera) & Fascaplysin & $\begin{array}{l}\text { Increase of acidic vacuolar organelles; upregulation of } \\
\text { LC3-II (by 4-chloro-fascaplysin derivative) }\end{array}$ \\
\hline Aaptos genus (Porifera) & Isoaaptamine & $\begin{array}{l}\text { Increase of acridine orange-positive } \\
\text { vacuoles; upregulation of LC3-II and p62/SQSTM1; } \\
\text { downregulation of mTOR }\end{array}$ \\
\hline K. flaccidum (Cnidaria) & $\begin{array}{l}3 \beta, 11 \text {-dihydroxy-9,11- } \\
\text { secogorgost-5-en-9-one }\end{array}$ & $\begin{array}{l}\text { Increase of acidic vesicular organelles; upregulation of } \\
\text { LC3-II and p62 }\end{array}$ \\
\hline C. virginica (Mollusca) & $\begin{array}{l}N \text {-methylaminoethyl } \\
\text { phosphonate }\end{array}$ & $\begin{array}{l}\text { Increase of fluorescent autophagosomes; upregulation } \\
\text { of beclin-1 }\end{array}$ \\
\hline $\begin{array}{c}\text { A. lixula } \\
\text { (Echinodermata) }\end{array}$ & $\begin{array}{l}\text { Cell-free aqueous extracts of the } \\
\text { coelomic fluid }\end{array}$ & $\begin{array}{l}\text { Increase of acidic vesicular organelles; upregulation of } \\
\text { beclin-1, LC3-II, and total LC3 }\end{array}$ \\
\hline $\begin{array}{c}\text { H. tubulosa } \\
\text { (Echinodermata) }\end{array}$ & $\begin{array}{l}\text { Cell-free aqueous extracts of the } \\
\text { coelomic fluid }\end{array}$ & $\begin{array}{l}\text { Increase of acidic vesicular organelles; upregulation of } \\
\text { beclin-1, LC3-II, and total LC3; possible mitophagy }\end{array}$ \\
\hline
\end{tabular}


Funding: This research was funded by the University of Palermo (Italy), grants FFR 2019 and 2020.

Institutional Review Board Statement: Not applicable.

Informed Consent Statement: Not applicable.

Conflicts of Interest: The authors declare no conflict of interest.

\section{References}

1. Chun, Y.; Kim, J. Autophagy: An Essential Degradation Program for Cellular Homeostasis and Life. Cells 2018, 7, 278. [CrossRef] [PubMed]

2. Caradonna, F.; Cruciata, I.; Luparello, C. Nutrigenetics, nutrigenomics and phenotypic outcomes of dietary low-dose alcohol consumption in the suppression and induction of cancer development: Evidence from in vitro studies. Crit. Rev. Food Sci. Nutr. 2020, 8, 1-32, epub ahead of print. [CrossRef] [PubMed]

3. Ravikumar, B.; Sarkar, S.; Davies, J.E.; Futter, M.; Garcia-Arencibia, M.; Green-Thompson, Z.W.; Jimenez-Sanchez, M.; Korolchuk, V.I.; Lichtenberg, M.; Luo, S.; et al. Regulation of mammalian autophagy in physiology and pathophysiology. Physiol. Rev. 2010, 90, 1383-1435. [CrossRef]

4. Al-Bari, M.A.A.; Xu, P. Molecular regulation of autophagy machinery by mTOR-dependent and -independent pathways. Ann. N. Y. Acad. Sci. 2020, 1467, 3-20. [CrossRef] [PubMed]

5. Klionsky, D.J.; Abdel-Aziz, A.K.; Abdelfatah, S.; Abdellatif, M.; Abdoli, A.; Abel, S.; Abeliovich, H.; Abildgaard, M.H.; Abudu, Y.P.; Acevedo-Arozena, A.; et al. Guidelines for the use and interpretation of assays for monitoring autophagy (4th edition). Autophagy 2021, 8, 1-382. [CrossRef]

6. Yun, C.W.; Lee, S.H. The Roles of Autophagy in Cancer. Int. J. Mol. Sci. 2018, 19, 3466. [CrossRef]

7. Lazova, R.; Camp, R.L.; Klump, V.; Siddiqui, S.F.; Amaravadi, R.K.; Pawelek, J.M. Punctate LC3B expression is a common feature of solid tumors and associated with proliferation, metastasis, and poor outcome. Clin. Cancer Res. 2012, 18, 370-379. [CrossRef]

8. Wang, M.C.; Wu, A.G.; Huang, Y.Z.; Shao, G.L.; Ji, S.F.; Wang, R.W.; Yuan, H.J.; Fan, X.L.; Zheng, L.H.; Jiao, Q.L. Autophagic regulation of cell growth by altered expression of Beclin 1 in triple-negative breast cancer. Int. J. Clin. Exp. Med. 2015, 8, 7049-7058. [PubMed]

9. Librizzi, M.; Longo, A.; Chiarelli, R.; Amin, J.; Spencer, J.; Luparello, C. Cytotoxic effects of Jay Amin hydroxamic acid (JAHA), a ferrocene-based class I histone deacetylase inhibitor, on triple-negative MDA-MB231 breast cancer cells. Chem. Res. Toxicol. 2012, 25, 2608-2616. [CrossRef]

10. Librizzi, M.; Tobiasch, E.; Luparello, C. The conditioned medium from osteo-differentiating human mesenchymal stem cells affects the viability of triple negative MDA-MB231 breast cancer cells. Cell Biochem. Funct. 2016, 34, 7-15. [CrossRef] [PubMed]

11. Librizzi, M.; Spencer, J.; Luparello, C. Biological Effect of a Hybrid Anticancer Agent Based on Kinase and Histone Deacetylase Inhibitors on Triple-Negative (MDA-MB231) Breast Cancer Cells. Int. J. Mol. Sci. 2016, 17, 1235. [CrossRef]

12. Luparello, C.; Asaro, D.M.L.; Cruciata, I.; Hassell-Hart, S.; Sansook, S.; Spencer, J.; Caradonna, F. Cytotoxic Activity of the Histone Deacetylase 3-Selective Inhibitor Pojamide on MDA-MB-231 Triple-Negative Breast Cancer Cells. Int. J. Mol. Sci. 2019, $20,804$. [CrossRef] [PubMed]

13. Maycotte, P.; Thorburn, A. Targeting autophagy in breast cancer. World J. Clin. Oncol. 2014, 5, 224-240. [CrossRef] [PubMed]

14. Folkerts, H.; Hilgendorf, S.; Vellenga, E.; Bremer, E.; Wiersma, V.R. The multifaceted role of autophagy in cancer and the microenvironment. Med. Res. Rev. 2019, 39, 517-560. [CrossRef] [PubMed]

15. Cocco, S.; Leone, A.; Piezzo, M.; Caputo, R.; Di Lauro, V.; Di Rella, F.; Fusco, G.; Capozzi, M.; Gioia, G.d.; Budillon, A.; et al. Targeting Autophagy in Breast Cancer. Int. J. Mol. Sci. 2020, 21, 7836. [CrossRef]

16. Malve, H. Exploring the ocean for new drug developments: Marine pharmacology. J. Pharm. Bioallied Sci. $2016,8,83-91$. [CrossRef] [PubMed]

17. Barbosa, A.J.M.; Roque, A.C.A. Free Marine Natural Products Databases for Biotechnology and Bioengineering. Biotechnol. J. 2019, 14, e1800607. [CrossRef] [PubMed]

18. Mayekar, T.S.; Salgaonkar, A.A.; Koli, J.M.; Patil, P.; Chaudhari, A.; Murkar, A.; Salvi, S.; Surve, D.; Jadhav, R.; Kazi, T. Marine Biotechnology: Bioactive Natural Products and their Applications. Available online: http://aquafind.com/articles/Marine-Biot echnology.php (accessed on 19 March 2021).

19. Saha, M.; Berdalet, E.; Carotenuto, Y.; Fink, P.; Harder, T.; John, U.; Not, F.; Pohnert, G.; Potin, P.; Selander, E.; et al. Using chemical language to shape future marine health. Front. Ecol. Environ. 2019, 17, 530-537. [CrossRef]

20. Lazzara, V.; Arizza, V.; Luparello, C.; Mauro, M.; Vazzana, M. Bright Spots in the Darkness of Cancer: A Review of StarfishesDerived Compounds and Their Anti-Tumor Action. Mar. Drugs 2019, 17, 617. [CrossRef]

21. Mauro, M.; Lazzara, V.; Punginelli, D.; Arizza, V.; Vazzana, M. Antitumoral compounds from vertebrate sister group: A review of Mediterranean ascidians. Dev. Comp. Immunol. 2020, 108, 103669. [CrossRef]

22. Luparello, C.; Mauro, M.; Lazzara, V.; Vazzana, M. Collective Locomotion of Human Cells, Wound Healing and Their Control by Extracts and Isolated Compounds from Marine Invertebrates. Molecules 2020, 25, 2471. [CrossRef] [PubMed]

23. Luparello, C.; Mauro, M.; Arizza, V.; Vazzana, M. Histone Deacetylase Inhibitors from Marine Invertebrates. Biology 2020,9 , 429. [CrossRef] [PubMed] 
24. Wang, C.-H.; Doan, C.T.; Nguyen, V.B.; Nguyen, A.D.; Wang, S.-L. Reclamation of Fishery Processing Waste: A Mini-Review. Molecules 2019, 24, 2234. [CrossRef]

25. Šimat, V.; Elabed, N.; Kulawik, P.; Ceylan, Z.; Jamroz, E.; Yazgan, H.; Čagalj, M.; Regenstein, J.M.; Özogul, F. Recent Advances in Marine-Based Nutraceuticals and Their Health Benefits. Mar. Drugs 2020, 18, 627. [CrossRef] [PubMed]

26. Chiarelli, R.; Martino, C.; Agnello, M.; Bosco, L.; Roccheri, M.C. Autophagy as a defense strategy against stress: Focus on Paracentrotus lividus sea urchin embryos exposed to cadmium. Cell Stress Chaperones 2016, 21, 19-27. [CrossRef]

27. Song, Q.; Liu, H.; Zhen, H.; Zhao, B. Autophagy and its role in regeneration and remodeling within invertebrate. Cell Biosci. 2020, 10, 111. [CrossRef]

28. Van Soest, R.W.; Boury-Esnault, N.; Vacelet, J.; Dohrmann, M.; Erpenbeck, D.; De Voogd, N.J.; Santodomingo, N.; Vanhoorne, B.; Kelly, M.; Hooper, J.N. Global diversity of sponges (Porifera). PLoS ONE 2012, 7, e35105. [CrossRef]

29. Invertebrates of the Coral Sea. Haliclona sp. Claudia Tay. 2012. Available online: https://www.gbri.org.au/Classes/Holothuriaat ra\%7CEmilyPurton/Haliclonasp\%7CClaudiaTay.aspx (accessed on 23 March 2021).

30. Yamazaki, H.; Wewengkang, D.S.; Kanno, S.; Ishikawa, M.; Rotinsulu, H.; Mangindaan, R.E.; Namikoshi, M. Papuamine and haliclonadiamine, obtained from an Indonesian sponge Haliclona sp., inhibited cell proliferation of human cancer cell lines. Nat. Prod. Res. 2013, 27, 1012-1015. [CrossRef]

31. Kanno, S.; Yomogida, S.; Tomizawa, A.; Yamazaki, H.; Ukai, K.; Mangindaan, R.E.; Namikoshi, M.; Ishikawa, M. Papuamine causes autophagy following the reduction of cell survival through mitochondrial damage and JNK activation in MCF-7 human breast cancer cells. Int. J. Oncol. 2013, 43, 1413-1419. [CrossRef] [PubMed]

32. Killackey, S.A.; Philpott, D.J.; Girardin, S.E. Mitophagy pathways in health and disease. J. Cell Biol. 2020, 219, e202004029. [CrossRef]

33. Kanno, S.I.; Yomogida, S.; Tomizawa, A.; Yamazaki, H.; Ukai, K.; Mangindaan, R.E.; Namikoshi, M.; Ishikawa, M. Combined effect of papuamine and doxorubicin in human breast cancer MCF-7 cells. Oncol. Lett. 2014, 8, 547-550. [CrossRef]

34. Min, H.Y.; Jung, Y.; Park, K.H.; Lee, H.Y. Papuamine Inhibits Viability of Non-small Cell Lung Cancer Cells by Inducing Mitochondrial Dysfunction. Anticancer Res. 2020, 40, 323-333. [CrossRef]

35. Haliclona caerulea (Hechtel, 1965) Blue Caribbean Sponge. Available online: https://www.sealifebase.ca/summary/Haliclona-c aerulea.html\# (accessed on 24 March 2021).

36. Carneiro, R.F.; de Melo, A.A.; de Almeida, A.S.; Moura Rda, M.; Chaves, R.P.; de Sousa, B.L.; do Nascimento, K.S.; Sampaio, S.S.; Lima, J.P.; Cavada, B.S.; et al. H-3, a new lectin from the marine sponge Haliclona caerulea: Purification and mass spectrometric characterization. Int. J. Biochem. Cell Biol. 2013, 45, 2864-2873. [CrossRef]

37. do Nascimento-Neto, L.G.; Cabral, M.G.; Carneiro, R.F.; Silva, Z.; Arruda, F.V.S.; Nagano, C.S.; Fernandes, A.R.; Sampaio, A.H.; Teixeira, E.H.; Videira, P.A. Halilectin-3, a Lectin from the Marine Sponge Haliclona caerulea, Induces Apoptosis and Autophagy in Human Breast Cancer MCF7 Cells Through Caspase-9 Pathway and LC3-II Protein Expression. Anti-cancer Agents Med. Chem. 2018, 18, 521-528. [CrossRef]

38. Bijukumar, A.; Nair, A.S. (Eds.) Marine Biodiversity Informatics for Kerala. Available online: http://www.keralamarinelife.in (accessed on 25 March 2021).

39. Keyzers, R.A.; Daoust, J.; Davies-Coleman, M.T.; Van Soest, R.; Balgi, A.; Donohue, E.; Roberge, M.; Andersen, R.J. Autophagymodulating aminosteroids isolated from the sponge Cliona celata. Org. Lett. 2008, 10, 2959-2962. [CrossRef] [PubMed]

40. Forestieri, R.; Donohue, E.; Balgi, A.; Roberge, M.; Andersen, R.J. Synthesis of clionamine B, an autophagy stimulating aminosteroid isolated from the sponge Cliona celata. Org. Lett. 2013, 15, 3918-3921. [CrossRef] [PubMed]

41. Bergquist, P.R.; de Cook, S.C. Family Pseudoceratinidae Carter, 1885. In Systema Porifera: A Guide to the Classification of Sponges; Hooper, J.N.A., Van Soest, R.W.M., Eds.; Kluwer Academic/Plenum Publishers: New York, NY, USA, 2002 ; pp. 1086-1088.

42. Kim, D.; Lee, I.S.; Jung, J.H.; Yang, S.I. Psammaplin A, a natural bromotyrosine derivative from a sponge, possesses the antibacterial activity against methicillin-resistant Staphylococcus aureus and the DNA gyrase-inhibitory activity. Arch. Pharm. Res. 1999, 22, 25-29. [CrossRef] [PubMed]

43. Tabudravu, J.N.; Eijsink, V.G.; Gooday, G.W.; Jaspars, M.; Komander, D.; Legg, M.; Synstad, B.; van Aalten, D.M. Psammaplin A, a chitinase inhibitor isolated from the Fijian marine sponge Aplysinella rhax. Bioorg. Med. Chem. 2002, 10, 1123-1128. [CrossRef]

44. Kim, D.H.; Shin, J.; Kwon, H.J. Psammaplin A is a natural prodrug that inhibits class I histone deacetylase. Exp. Mol. Med. 2007, 39, 47-55. [CrossRef] [PubMed]

45. Piña, I.C.; Gautschi, J.T.; Wang, G.Y.; Sanders, M.L.; Schmitz, F.J.; France, D.; Cornell-Kennon, S.; Sambucetti, L.C.; Remiszewski, S.W.; Perez, L.B.; et al. Psammaplins from the sponge Pseudoceratina purpurea: Inhibition of both histone deacetylase and DNA methyltransferase. J. Org. Chem. 2003, 68, 3866-3873. [CrossRef]

46. Kim, T.H.; Kim, H.S.; Kang, Y.J.; Yoon, S.; Lee, J.; Choi, W.S.; Jung, J.H.; Kim, H.S. Psammaplin A induces Sirtuin 1-dependent autophagic cell death in doxorubicin-resistant MCF-7/adr human breast cancer cells and xenografts. Biochim. Biophys. Acta 2015, 1850, 401-410. [CrossRef]

47. DeVorkin, L.; Choutka, C.; Gorski, S.M. The Interplay between Autophagy and Apoptosis. In Autophagy: Cancer, Other Pathologies, Inflammation, Immunity, Infection, and Aging; Hayat, M.A., Ed.; Academic Press: Amsterdam, The Netherlands, 2014 ; pp. 369-383.

48. Hu, W.; Chen, S.; Thorne, R.F.; Wu, M. TP53, TP53 Target Genes (DRAM, TIGAR), and Autophagy. Adv. Exp. Med. Biol. 2019, 1206, 127-149. [CrossRef] [PubMed]

49. Kreis, N.-N.; Louwen, F.; Yuan, J. The Multifaceted p21 (Cip1/Waf1/CDKN1A) in Cell Differentiation, Migration and Cancer Therapy. Cancers 2019, 11, 1220. [CrossRef] 
50. Richmond, M. (Ed.) A Guide to the Seashores of Eastern Africa and the Western Indian Ocean Islands; The Swedish International Development Co-operation: Stockholm, Sweden, 1997.

51. Kobayashi, M.; Kawazoe, K.; Kitagawa, I. Araguspongines B, C, D, E, F, G, H, and J, new vasodilative bis-1-oxaquinolizidine alkaloids from an okinawan marine sponge, Xestospongia sp. Chem. Pharm. Bull. 1989, 37, 1676-1678. [CrossRef] [PubMed]

52. Orabi, K.Y.; El Sayed, K.A.; Hamann, M.T.; Dunbar, D.C.; Al-Said, M.S.; Higa, T.; Kelly, M. Araguspongines K and L, new bioactive bis-1-oxaquinolizidine N-oxide alkaloids from Red Sea specimens of Xestospongia exigua. J. Nat. Prod. 2002, 65, $1782-1785$. [CrossRef] [PubMed]

53. Akl, M.R.; Ayoub, N.M.; Ebrahim, H.Y.; Mohyeldin, M.M.; Orabi, K.Y.; Foudah, A.I.; El Sayed, K.A. Araguspongine C induces autophagic death in breast cancer cells through suppression of c-Met and HER2 receptor tyrosine kinase signaling. Mar. Drugs 2015, 13, 288-311. [CrossRef]

54. Ebrahim, H.Y.; El Sayed, K.A. Discovery of Novel Antiangiogenic Marine Natural Product Scaffolds. Mar. Drugs 2016, 14, 57. [CrossRef] [PubMed]

55. Wang, Q.; Tang, X.L.; Luo, X.C.; de Voog, N.J.; Li, P.L.; Li, G.Q. Aplysinopsin-type and Bromotyrosine-derived Alkaloids from the South China Sea Sponge Fascaplysinopsis reticulata. Sci. Rep. 2019, 9, 2248. [CrossRef]

56. Segraves, N.L.; Robinson, S.J.; Garcia, D.; Said, S.A.; Fu, X.; Schmitz, F.J; Pietraszkiewicz, H.; Valeriote, F.A.; Crews, P. Comparison of fascaplysin and related alkaloids: A study of structures, cytotoxicities, and sources. J. Nat. Prod. 2004, 67, 783-792. [CrossRef]

57. Zheng, Y.L.; Lu, X.L.; Lin, J.; Chen, H.M.; Yan, X.J.; Wang, F.; Xu, W.F. Direct effects of fascaplysin on human umbilical vein endothelial cells attributing the anti-angiogenesis activity. Biomed. Pharmacother. 2010, 64, 527-533. [CrossRef]

58. Chen, S.; Guan, X.; Wang, L.L.; Li, B.; Sang, X.B.; Liu, Y.; Zhao, Y. Fascaplysin inhibit ovarian cancer cell proliferation and metastasis through inhibiting CDK4. Gene 2017, 635, 3-8. [CrossRef] [PubMed]

59. Rath, B.; Hochmair, M.; Plangger, A.; Hamilton, G. Anticancer Activity of Fascaplysin against Lung Cancer Cell and Small Cell Lung Cancer Circulating Tumor Cell Lines. Mar. Drugs 2018, 16, 383. [CrossRef]

60. Sharma, S.; Guru, S.K.; Manda, S.; Kumar, A.; Mintoo, M.J.; Prasad, V.D.; Sharma, P.R.; Mondhe, D.M.; Bharate, S.B.; Bhushan, S. A marine sponge alkaloid derivative 4-chloro fascaplysin inhibits tumor growth and VEGF mediated angiogenesis by disrupting $\mathrm{PI} 3 \mathrm{~K} / \mathrm{Akt} / \mathrm{mTOR}$ signaling cascade. Chem. Biol. Interact. 2017, 275, 47-60. [CrossRef]

61. Dyshlovoy, S.A.; Fedorov, S.N.; Shubina, L.K.; Kuzmich, A.S.; Bokemeyer, C.; Keller-von Amsberg, G.; Honecker, F. Aaptamines from the marine sponge Aaptos sp. display anticancer activities in human cancer cell lines and modulate AP-1-, NF-kB-, and p53-dependent transcriptional activity in mouse JB6 Cl41 cells. Biomed. Res. Int. 2014, 2014, 469309. [CrossRef]

62. Wu, C.F.; Lee, M.G.; El-Shazly, M.; Lai, K.H.; Ke, S.C.; Su, C.W.; Shih, S.P.; Sung, P.J.; Hong, M.C.; Wen, Z.H.; et al. Isoaaptamine Induces T-47D Cells Apoptosis and Autophagy via Oxidative Stress. Mar. Drugs 2018, 16, 18. [CrossRef] [PubMed]

63. Alderslade, P. Four new genera of soft corals (Coelenterata: Octocorallia), with notes on the classification of some established taxa. Zool. Med. Leiden. 2000, 74, 237-249.

64. Weng, J.R.; Chiu, C.F.; Hu, J.L.; Feng, C.H.; Huang, C.Y.; Bai, L.Y.; Sheu, J.H. A Sterol from Soft Coral Induces Apoptosis and Autophagy in MCF-7 Breast Cancer Cells. Mar. Drugs 2018, 16, 238. [CrossRef] [PubMed]

65. Kotta-Loizou, I.; Giaginis, C.; Theocharis, S. The role of peroxisome proliferator-activated receptor- $\gamma$ in breast cancer. Anticancer Agents Med. Chem. 2012, 12, 1025-1044. [CrossRef] [PubMed]

66. Tsai, C.R.; Huang, C.Y.; Chen, B.W.; Tsai, Y.Y.; Shih, S.P.; Hwang, T.L.; Dai, C.F.; Wang, S.Y.; Sheu, J.H. New bioactive steroids from the soft coral Klyxum flaccidum. RSC Adv. 2015, 5, 12546-12554. [CrossRef]

67. Matsubara, T.; Hayashi, A. Identification of molecular species of ceramide aminoethylphosphonate from oyster adductor by gas-liquid chromatography-mass spectrometry. Biochim. Biophys. Acta 1973, 296, 171-178.

68. Matsubara, T. The structure and distribution of ceramide aminoethylphosphonates in the oyster (Ostrea gigas). Biochim. Biophys. Acta 1975, 388, 353-360. [PubMed]

69. Moro, K.; Nagahashi, M.; Gabriel, E.; Takabe, K.; Wakai, T. Clinical application of ceramide in cancer treatment. Breast Cancer 2019, 26, 407-415. [CrossRef] [PubMed]

70. Chintalapati, M.; Truax, R.; Stout, R.; Portier, R.; Losso, J.N. In vitro and in vivo anti-angiogenic activities and inhibition of hormone-dependent and -independent breast cancer cells by ceramide methylaminoethylphosphonate. J. Agric. Food Chem. 2009, 57, 5201-5210. [CrossRef]

71. Beg, A.A.; Ruben, S.M.; Scheinman, R.I.; Haskill, S.; Rosen, C.A.; Baldwin, A.S., Jr. I kappa B interacts with the nuclear localization sequences of the subunits of NF-kappa B: A mechanism for cytoplasmic retention. Genes Dev. 1992, 6, 1899-1913. [CrossRef] [PubMed]

72. Monkkonen, T.; Debnath, J. Inflammatory signaling cascades and autophagy in cancer. Autophagy 2018, 14, 190-198. [CrossRef]

73. Cui, J.; Shen, H.-M.; Lim, L.H.K. The Role of Autophagy in Liver Cancer: Crosstalk in Signaling Pathways and Potential Therapeutic Targets. Pharmaceuticals 2020, 13, 432. [CrossRef]

74. Kma, L.; Baruah, T.J. The interplay of ROS and the PI3K/Akt pathway in autophagy regulation. Biotechnol. Appl. Biochem. 2021. epub ahead of print. [CrossRef]

75. Luparello, C.; Ragona, D.; Asaro, D.M.L.; Lazzara, V.; Affranchi, F.; Arizza, V.; Vazzana, M. Cell-Free Coelomic Fluid Extracts of the Sea Urchin Arbacia lixula Impair Mitochondrial Potential and Cell Cycle Distribution and Stimulate Reactive Oxygen Species Production and Autophagic Activity in Triple-Negative MDA-MB231 Breast Cancer Cells. J. Mar. Sci. Eng. 2020, 8 , 261. [CrossRef] 
76. Vazzana, M.; Siragusa, T.; Arizza, V.; Buscaino, G.; Celi, M. Cellular responses and HSP70 expression during wound healing in Holothuria tubulosa (Gmelin, 1788). Fish Shellfish Immunol. 2015, 42, 306-315. [CrossRef]

77. Mauro, M.; Queiroz, V.; Arizza, V.; Campobello, D.; Custódio, M.R.; Chiaramonte, M.; Vazzana, M. Humoral responses during wound healing in Holothuria tubulosa (Gmelin, 1788). Comp. Biochem. Physiol. B Biochem. Mol. Biol. 2021, 253, 110550. [CrossRef]

78. Martino, C.; Bonaventura, R.; Byrne, M.; Roccheri, M.; Matranga, V. Effects of exposure to gadolinium on the development of geographically and phylogenetically distant sea urchins species. Mar. Environ. Res. 2017, 128, 98-106. [CrossRef]

79. Martín, J.; Hidalgo, F.; García-Corcoles, M.T.; Ibáñez-Yuste, A.J.; Alonso, E.; Vilchez, J.L.; Zafra-Gómez, A. Bioaccumulation of perfluoroalkyl substances in marine echinoderms: Results of laboratory-scale experiments with Holothuria tubulosa Gmelin, 1791. Chemosphere 2019, 215, 261-271. [CrossRef] [PubMed]

80. Vazzana, M.; Mauro, M.; Ceraulo, M.; Dioguardi, M.; Papale, E.; Mazzola, S.; Arizza, V.; Beltrame, F.; Inguglia, L.; Buscaino, G. Underwater high frequency noise: Biological responses in sea urchin Arbacia lixula (Linnaeus, 1758). Comp. Biochem. Physiol. A Mol. Integr. Physiol. 2020, 242, 110650. [CrossRef] [PubMed]

81. Luparello, C.; Ragona, D.; Asaro, D.M.L.; Lazzara, V.; Affranchi, F.; Celi, M.; Arizza, V.; Vazzana, M. Cytotoxic Potential of the Coelomic Fluid Extracted from the Sea Cucumber Holothuria tubulosa against Triple-Negative MDA-MB231 Breast Cancer Cells. Biology 2019, 8, 76. [CrossRef] [PubMed]

82. Khotimchenko, Y. Pharmacological Potential of Sea Cucumbers. Int. J. Mol. Sci. 2018, 19, 1342. [CrossRef]

83. Abdelkarem, F.M.; Desoky, E.K.; Nafady, A.M.; Allam, A.E.; Mahdy, A.; Ashour, A.; Shimizu, K. Diadema setosum: Isolation of bioactive secondary metabolites with cytotoxic activity toward human cervical cancer. Nat. Prod. Res. 2020, 4, 1-4. [CrossRef]

84. Yurasakpong, L.; Apisawetakan, S.; Pranweerapaiboon, K.; Sobhon, P.; Chaithirayanon, K. Holothuria scabra Extract Induces Cell Apoptosis and Suppresses Warburg Effect by Down-Regulating Akt/mTOR/HIF-1 Axis in MDA-MB-231 Breast Cancer Cells. Nutr. Cancer 2020, 3, 1-12. [CrossRef] [PubMed]

85. Mohamed, A.S. Echinochrome Exhibits Antitumor Activity against Ehrlich Ascites Carcinoma in Swiss Albino Mice. Nutr. Cancer 2021, 73, 124-132. [CrossRef]

86. Tasdemir, E.; Maiuri, M.C.; Tajeddine, N.; Vitale, I.; Criollo, A.; Vicencio, J.M.; Hickman, J.A.; Geneste, O.; Kroemer, G. Cell cycle-dependent induction of autophagy, mitophagy and reticulophagy. Cell Cycle 2007, 6, 2263-2267. [CrossRef]

87. Guo, W.; Wang, Y.; Wang, Z.; Wang, Y.P.; Zheng, H. Inhibiting autophagy increases epirubicin's cytotoxicity in breast cancer cells Cancer Sci. 2016, 107, 1610-1621. [CrossRef]

88. Poole, L.P.; Macleod, K.F. Mitophagy in tumorigenesis and metastasis. Cell. Mol. Life Sci. 2021. [CrossRef] [PubMed]

89. Breast Cancer. Available online: https:/ / www.who.int/news-room/fact-sheets/detail/breast-cancer\#: :text=In \%202020\%2C\% 20there\%20were\%202.3, the \%20world's\%20most \%20prevalent $\% 20$ cancer (accessed on 28 April 2021).

90. Sung, H.; Ferlay, J.; Siegel, R.L.; Laversanne, M.; Soerjomataram, I.; Jemal, A.; Bray, F. Global cancer statistics 2020: GLOBOCAN estimates of incidence and mortality worldwide for 36 cancers in 185 countries. CA Cancer J. Clin. 2021. [CrossRef] [PubMed]

91. Barabadi, H.; Mahjoub, M.A.; Tajani, B.; Ahmadi, A.; Junejo, J.; Saravanan, M. Emerging Theranostic Biogenic Silver Nanomaterials for Breast Cancer: A Systematic Review. J. Cluster Sci. 2019, 30, 259-279. [CrossRef]

92. Saravanan, M.; Vahidi, H.; Medina Cruz, D.; Vernet-Crua, A.; Mostafavi, E.; Stelmach, R.; Webster, T.J.; Mahjoub, M.A.; Rashedi, M.; Barabadi, H. Emerging Antineoplastic Biogenic Gold Nanomaterials for Breast Cancer Therapeutics: A Systematic Review. Int. J. Nanomed. 2020, 15, 3577-3595. [CrossRef] [PubMed]

93. Deretic, V. Autophagy in inflammation, infection, and immunometabolism. Immunity 2021, 54, 437-453. [CrossRef]

94. Kouroumalis, E.; Voumvouraki, A.; Augoustaki, A.; Samonakis, D.N. Autophagy in liver diseases. World J. Hepatol. 2021, 13, 6-65. [CrossRef] [PubMed]

95. Wargasetia, T.L.; Widodo, N. The Link of Marine Products with Autophagy-Associated Cell Death in Cancer Cell. Curr. Pharmacol. Rep. 2019, 5, 35-42. [CrossRef] 